\title{
IDENTIFIKASI PERUBAHAN PENGGUNAAN LAHAN DENGAN MENGGUNAKAN CITRA SATELIT DI DISTRIK MUSATFAK KABUPATEN JAYAWIJAYA
}

\author{
Lukmar Hilungka ${ }^{1}$ Grace F. E. South $^{2}$, Helena Sri Sulastriningsih, ${ }^{3}$ \\ ${ }^{1}$ Mahasiswa Program Studi Geografi, Fakultas Ilmu Sosial, Universitas Negeri Manado \\ ${ }^{2,3}$ Program Studi Geografi, Fakultas Ilmu Sosial, Universitas Negeri Manado \\ email : lukmarhilungka20@gmail.com
}

\begin{abstract}
The identification of land-use changes in the Musatfak District of Jayawijaya Regency is based on the decreasing level of community income and the change in land-use functions. The purpose of this study is to calculate land use changes in Musatfak District, Jayawijaya Regency in 2015-2020 and to examine the factors that cause changes in land use. The research method is descriptive qualitative and overlays spatial analysis of data using ArGIS. The results showed changes in land use in Musatfak District, Jayawijaya Regency in 20152020, respectively for horticultural land 1,787 square hectares, paddy field 15 hectares square, and sleeping area 19 square hectares. It is known that the causes of land change include: horticultural land and paddy fields are converted into idle land, because the people in Musatfak District do not cultivate the land because some have settled in the city, working to sell and buy wood planks, beams, and lima-lima.
\end{abstract}

Keywords: Identification, Land Use, Satellite Image, Musatfak District

\begin{abstract}
Abstrak: Identifikasi perubahan penggunaan lahan di Distrik Musatfak Kabupaten Jayawijaya didasari pada tingkat pendapatan masyarakat yang menurun dan alih fungsi penggunaan lahan. Tujuan penelitian ini adalah menghitung perubahan penggunaan lahan di Distrik Musatfak Kabupaten Jayawijaya tahun 2015-2020 dan mengkaji faktor-faktor penyebab terjadi perubahan penggunaan lahan tersebut. Metode penelitian bersifat deskriptif kualitatif dan analisis spasial data secara overlay menggunakan ArGIS. Hasil penelitian menunjukan perubahan penggunaan lahan di Distrik Musatfak Kabupaten Jayawijaya tahun 2015-2020, masing-masing untuk lahan holtikultural 1,787 hektar persegi, lahan sawah 15 hektar persegi, dan lahan tidur 19 hektar persegi. Diketahui faktor-faktor penyebab terjadinya perubahan lahan, antara lain: lahan holtikultural dan lahan sawah diubah menjadi lahan tidur, karena masyarakat di Distrik Musatfak tidak mengolah lahan tersebut akibat sebagian telah menetap ke kota, kerja jual beli kayu papan, balok, dan lima-lima.
\end{abstract}

Kata Kunci: Identifikasi, Penggunaan Lahan, Citra Satelit, Distrik Musatfak

\section{PENDAHULUAN}

Penggunaan teknologi penginderaan jauh dibidang geografi merupakan salah satu pilihan yang tepat untuk memperoleh data yang cepat, akurat dan relatif murah untuk mendeteksi perubahan penggunaan lahan. Pemanfaatan data citra untuk interpretasi penginderaan jauh memilik banyak keuntungan, karena dapat menyajikan informasi berbasis keruangan pada suatu kajian atau penelitian kewilayahan. Citra satelit mampu memberikan pandangan seecara menyeluruh atas suatu wilayah (synoptic overview). Kelebihan ini akan membuat analisis berbasis keruangan menjadi lebih praktis sebab hubungan keruangan antara suatu fenomena dengan fenomena lainnya dapat dilakukan dengan lebih mudah (Chen, Huang \& Xu, 2007).

Citra landsat 8 Citra merupakan citra satelit yang dapat diunduh secara gratis, akan tetapi tetap membutuhkan akses internet untuk memperolehnya. Kualitas citra landsat 8 setelah dilakukan pengelolaan citra memiliki resolusi $15 \mathrm{~m}$ dengan metode pankromatik apabila 